\title{
SMALL BUSINESS IN RUSSIA AS AN ECONOMIC AND SOCIAL PHENOMENON
}

Today small business is undoubtedly an important part of national economies all over the world. Problematics of small business development turned to one of the most popular areas of study for the Russian researchers in the 1990s. After the market reforms started, a large part of population believed that small business would become a source of wealth and prosperity as for them personally so for the society as a whole. This opinion united academic researchers and practitioners-entrepreneurs, so the activities of the latter gave the empirical material for the first. The main economic functions usually attributed to small businesses are the following: innovation, combating monopolies and maintain a competitive environment, combating unemployment and creating jobs, increasing income of the general population and, consequently, the expansion of consumer demand, increase the professional activity, the development of entrepreneurial skills, spirit, and traditions. Social role of small business is considered as an important institution of civil society and the kernel of the middle class formation as a basis for socio-political stability of the state. In the earlier research of the author it was concluded that in today Russia small business does not perform properly the functions attributed to it by economic theory. Its contribution to innovation is modest. Its antimonopoly role does not fit the theoretical position. The role in job creation is noticeable but it is not accompanied by the role in income creation and by the appropriate indicators of business productivity. The aim of current research is to identify and to explain the specifics of small business in Russia in context of economic theory and social processes based on statistical and factual information.

Keywords: small business, entrepreneurship, innovation, competitive environment, income in small businesses

* Peter the Great Saint-Petersburg Polytechnic University, Saint-Petersburg, Russia guzikova@mail.ru 


\section{INTRODUCTION}

Small business is an integral and indispensable element of a modern market economy. More than big business it is characterized by a direct relationship with the public that is determined by its mass, the predominant orientation to the needs of people, the spatial dispersal.

In different countries, the characteristics of small businesses vary within wide limits. This applies to the parameters according to which the entity belongs to the category of small businesses, as well as to the social position and role of small business, to the scope and areas of economic activity and to its results. However, in general, the state of small business is a reflection of the state of the economy and society, emerging in the country in a certain period of time. From this standpoint, in our opinion, it is necessary to analyze the state of small business for the decision-making on its regulation and development.

The aim of this paper is to identify and explain the specifics of small businesses in Russia in the context of economic theory and contemporary socioeconomic processes. In a study of Russian small business as a socio-economic phenomenon, by our view, it is necessary to take into account the heterogeneity of the territorial socio-economic development within the country.

\section{DATA SOURCES AND METHODOLOGY}

The present study is based on three types of information sources:

1) theoretical scientific works of modern researchers on the sociology of business and economics;

2) data from surveys of entrepreneurs, held in Russia for various purposes in the period from 2006 to 2014;

3) data of the state statistics presented on the official website of the Federal Service of State Statistics (Rosstat) www.gks.ru, collection of materials "Small and medium business in Russia", by the end of 2014, published by Rosstat in December 2015.

Starting in 2010, Rosstat has published the main indicators of small and medium-sized businesses annually by the results of SME surveys. It should be noted that in 2016, Rosstat plans to carry out total federal statistical supervision over the activities of small and medium-sized businesses for 2015. The results of total observations will clarify the data on the sector, which now is mainly collected on a sample basis. The first results should be published in 2017 on the site of Rosstat.

The methodology of the study constitutes logical analysis allowing to map the actual situation and theoretical models, methods of statistical analysis for structure and dynamics of complex objects and processes. 


\section{MAIN POSITIONS AND RESULTS}

\subsection{Social Portrait of Russian entrepreneur}

Small business in Russia appeared in the 80 s of the last century. In the framework of traditional economic structures no independent subjects of production were created for entrepreneurial initiatives, but they really became prerequisite for the development of small businesses. In the late 80 s the changes in political, social and economic spheres of the country provided for some enterprising people the opportunity to engage in business activities on a legal basis. First cooperatives, unions, business associations and members of cooperative movement were created; the Union of Soviet managers was established.

Neither in other countries nor in Russia a common economic theory of entrepreneurship has not yet established, although the need for such a theory is very relevant. In the development process of scientific understanding of business practices, as a rule, three waves reflecting the development of the theory of entrepreneurship are distinguished (Brunova, 2010).

The first wave came in the XVIII century and was associated with awareness of risk as a factor of business. The second wave was associated with the release of innovation as the main distinctive feature of the business. The founder of this strand was J. Schumpeter. The third wave focuses on the special personal qualities of the entrepreneur and the role of business as a regulatory principle in the economic system.

The current stage of development of entrepreneurship theory can be characterized as the fourth wave, the essence of which is the emphasis on the administrative aspect, and therefore - transition to a multi-level analysis of business problems becomes necessary (Rasskazova, 2008).

We agree with A.V. Kruglov (Kruglov, 204) who said that "the Russian business is quite a unique phenomenon", and even from the point of view of business the Russian and the foreign entrepreneurs solve basically different problems.

Researchers, for example P.A.Guryanov (Guryanov, 2011), note that the model of an entrepreneurial culture, which has begun to form in Russia since the late 80 s is significantly different from the traditional model, developed by the early 20th-century and largely determined by the Orthodox ethics, which was characterized by

- $\quad$ no ideas of wealth for wealth;

- confession of the righteousness of the wealth obtained by work;

- awareness of the necessity of public utility of entrepreneurship;

- charity as an essential condition for the salvation of soul;

- high level of trust and honesty in the business environment (Rumyantsev, 2008). 
According to researches, current motivation for doing business is quite different. Its priorities are shown in Tab. 1, which contains the results of Russian entrepreneurs surveys. Predominance of motives related to family and personal material interests is evident as well as low level of prestige and public benefit motives.

Table 1: Distribution of answers to the question

"What attracts you most in your work?" (Motivation structure, 2006)

\begin{tabular}{|l|c|}
\hline Motivation & $\%$ \\
\hline High income & 56.9 \\
\hline Ability to take the initiative & 27.7 \\
\hline Interesting work & 16.8 \\
\hline Ability to transfer their business by inheritance & 58.1 \\
\hline Reliable workplace, job security & 5.3 \\
\hline Ability to achieve something & 24.5 \\
\hline Possibility of career development, prestigious post & 3.9 \\
\hline Opportunity to work with highly qualified colleagues & 2.6 \\
\hline Possibility to benefit society, contribute to the revival of the economy & 7.9 \\
\hline Possibility to see certain results of your labor & 48.6 \\
\hline
\end{tabular}

By available data, $80 \%$ of entrepreneurs are men and $20 \%$ - women. Their average age varies from 30 to 45 . Most of them have got education, clearly understand their goals and the ways to achieve them, aware of the risks (Theoretical aspects, 2014). More than a half of entrepreneurs combine the functions of managers and owners (co-owners) of business. For most entrepreneurs doing business is the main occupation. However, there are also those who still keep their jobs in state institutions as a kind of insurance.

According to the Global Entrepreneurship Monitor, in 2013 in Russia 9.1\% of respondents considered they were businessmen (compared to $6.3 \%$ a year earlier), including $5.8 \%$ of respondents who called themselves starting businessmen. More than one third of those surveyed business owners consider they are "forced entrepreneurs" and have no other income opportunities. This figure in Russia is traditionally higher than in other countries with a similar economic structure (Edovina, 2014).

Not less than $14.5 \%$ of the respondents are in fly-by-night business (Edovina, 2014). The high share of illegal business can be attributed to the fact that in a period of low economic growth people are trying to find additional sources of income and are willing to take risks, including the risk of conflict with the law. 


\subsection{Economic results of small business}

Prior to 2015, the following criteria for inclusion of an economic entity for small businesses (Tab. 2) were established in Russia. Since 2015 value of revenue criterion have changed. For microenterprises the limit is set at the level of 800 mln rubles, for small businesses - 2 bln rubles. This change will make it more difficult to compare dynamic data in future.

\section{Table 2: Criteria for Small Business}

\begin{tabular}{|l|l|l|l|}
\hline $\begin{array}{c}\text { Category of } \\
\text { small businesses }\end{array}$ & $\begin{array}{c}\text { Employment in } \\
\text { the enterprise }\end{array}$ & $\begin{array}{c}\text { Revenue of the } \\
\text { enterprise }\end{array}$ & $\begin{array}{c}\text { The criterion of origin } \\
\text { independence }\end{array}$ \\
\hline Microenterprise & $<15$ persons & $<60 \mathrm{mln}$ rub. & $\begin{array}{l}\text { The share of Russian Federation, } \\
\text { subjects of Russian Federation, } \\
\text { municipalities, public and } \\
\text { religious organizations in the } \\
\text { capital of enterprise not more } \\
\text { than } 25 \% \text {, the share of foreign } \\
\text { legal entities and (or) legal } \\
\text { entities which are not SMEs - not } \\
\text { more than } 49 \% .\end{array}$ \\
\hline
\end{tabular}

In the theory of entrepreneurship simultaneous emergence of a large number of businesses supposes a certain social situation when the ideological, political and / or socio-economic conditions provoke so-called "entrepreneurial boom." There are three theoretical models that explain the quantitative growth and development of small business:

- in the model of economic downturn, unemployment is considered as the main factor contributing to the increase in the number of small businesses;

- in the revenue growth model, increasing the number of small enterprises is determined as response to increasing demand for products and services;

- in the innovation model, surge of new enterprises is explained by the emergence and development of new technologies. (Keeble, 1990)

During 2010-2014 the number of small businesses showed positive dynamics. The number of micro- and small enterprises in 5 years grew by $28 \%$ - from 1644.3 thousand in 2010 to $2,103.8$ thousand in 2014 . The number of microenterprises in 2014 increased by almost a third compared with 2010 and reached 1868.2 thousand.

In 2014, the sector of small and medium-sized businesses the most part was constituted by sole proprietors (unincorporated) -. 2.4 million or $53.3 \%$ of all the sector and microenterprises - 1.9 million or $41 \%$. Small businesses constituted 
$5.2 \%$. At the same time in the micro enterprises and individual businesses more than half of personnel of SME sector was employed - 55\%.

Economic indicators of small enterprises are given in Tab. 3.

Table 3: Main economic indicators of small enterprises, 2010-2014

\begin{tabular}{|l|c|c|c|c|c|c|c|c|c|c|}
\hline \multirow{2}{*}{ Indicator } & \multicolumn{7}{|c|}{ total } & \multicolumn{7}{|c|}{ Small enterprises } \\
\cline { 2 - 11 } & 2010 & 2011 & 2012 & 2013 & 2014 & 2010 & 2011 & 2012 & 2013 & 2014 \\
\hline $\begin{array}{l}\text { Number of enter- } \\
\text { prises (by end of } \\
\text { year), thous. }\end{array}$ & 1644.3 & 1836.4 & 2003.0 & 2063.1 & 2103.8 & 1415.2 & 1593.8 & 1760.0 & 1828.6 & 1868.2 \\
\hline $\begin{array}{l}\text { Averagenumber of } \\
\text { employees, without } \\
\text { external part, thous. }\end{array}$ & 9790.2 & 10421.9 & 10755.7 & 10775.2 & 10789.5 & 3320.0 & 3864.4 & 4248.9 & 4322.9 & 4431.1 \\
\hline $\begin{array}{l}\text { Revenueof enter- } \\
\text { prises bln rub. }\end{array}$ & 18933.8 & 22610.2 & 23463.7 & 24781.6 & 26392.2 & 5609.2 & 7028.3 & 8347.4 & 9101.3 & 9699.3 \\
\hline $\begin{array}{l}\text { Averagemonthly } \\
\text { salary of employees, } \\
\text { rub. }\end{array}$ & 12367 & 15743 & 16711 & 17948 & 19201 & 10612 & 12855 & 13898 & 15039 & 15774 \\
\hline $\begin{array}{l}\text { Revenueper } \\
\text { employee, mln. rub. }\end{array}$ & 1.93 & 2.17 & 2.18 & 2.30 & 2.45 & 1.69 & 1.82 & 1.96 & 2.11 & 2.19 \\
\hline $\begin{array}{l}\text { Theaverage salary in } \\
\text { economy, rub. }\end{array}$ & 20952 & 23369 & 26629 & 29792 & 32495 & 20952 & 23369 & 26629 & 29792 & 32495 \\
\hline $\begin{array}{l}\text { The ratioof average } \\
\text { salary in the small } \\
\text { business to that in } \\
\text { economy, \% }\end{array}$ & 59.02 & 67.37 & 62.76 & 60.24 & 59.09 & 50.65 & 55.01 & 52.19 & 50.48 & 48.54 \\
\hline
\end{tabular}

In our opinion, it is clear that salary about two times less than the average in the economy, whose purchasing power, in turn, significantly less than the purchasing power of average salary in developed countries, is not an attractive factor for employment in small business. The salary level confirms that for a large part of employees employment in small business is forced due to the lack of employment opportunities in large enterprises of the private and public sector, that the main motive for participation in small business to a large extent is the threat of unemployment and the complete loss of income. As the second reason that could explain such low salary reflected in official statistics should be specified a large illegal component in a small business.

As the positive reflecting the efficiency of small businesses faster growth of small business revenue compared to the growth of employment can be perceived. During 5 years revenue of small enterprises grew 1.31 times, while the number of employees increased by 1.10 times (for micro- enterprises corresponding figures were 1.73 and 1.33). However, if we take into account that the inflation annual rate was stable over $6 \%$, we can say, at best, about the constant revenue accompanied by the number of employee growth. Throughout the 5 year period, in one small business 6 persons were employed on average, in microenterprises - 3 persons. 
The number of small businesses distribution pattern in the federal districts of Russia in 2014, shows an uneven distribution of enterprises (Fig.1). According to the number of small enterprises, including micro, the Central Federal District and the Volga Federal District leading respectively, 27.3\% and $17.5 \%$ of the total number of small and micro enterprises. In third place Northwestern Federal District, which has $15.8 \%$ of all small businesses, on the fourth - Siberian Federal District with 14, 4\% of all micro and small enterprises. Other districts do not exceed $10 \%$ of micro and small enterprises total number.

The regional structure of employment in small business is the following. Central FD is leading in terms of employment in small enterprises - it occupies $30.6 \%$ of the total number of employees in the segment of small and micro enterprises. In the second place - the Volga FD employing 21.4\%, in the third place - Siberian FD with $12.6 \%$ of the employed.

Figures of small and micro-enterprises revenue for the districts listed above are, respectively, $36.6 \%, 18.3 \%$ and $10.7 \%$.

Fig. 1: Regional structure of the number of small businesses, the number of employees and revenue

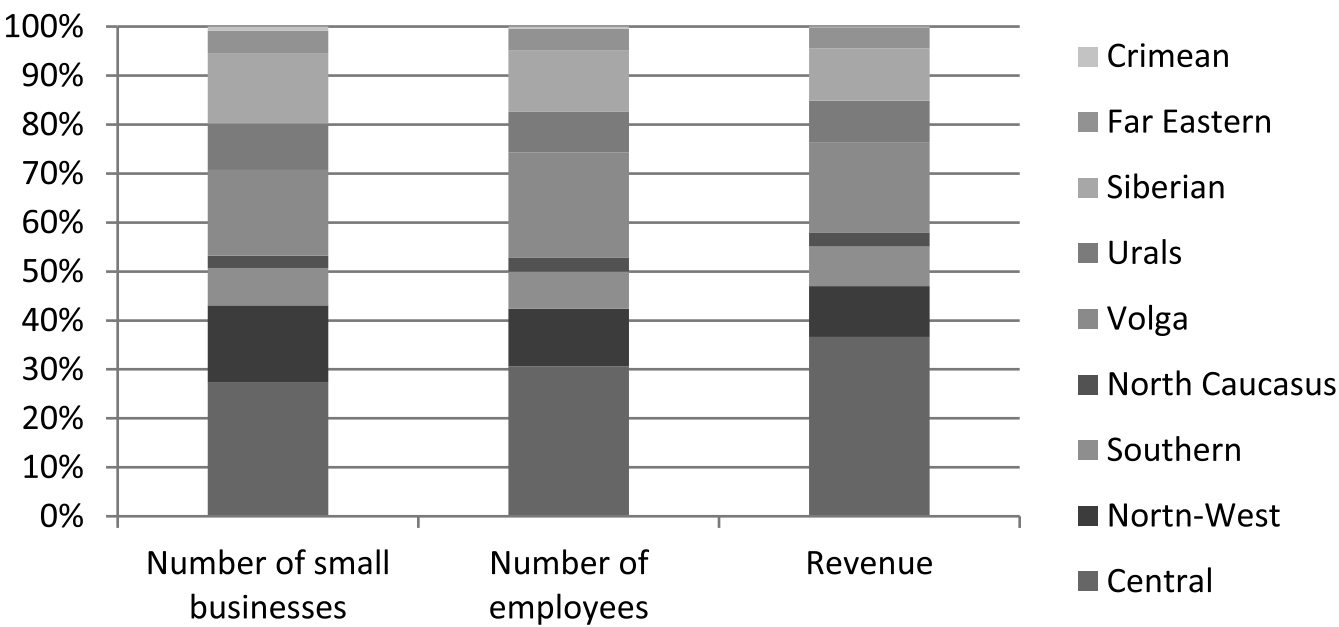

The branch structure of small business in 2014 is shown in Fig. 2. The share of enterprises engaged in trade and repair accounted for $38.7 \%$. $20.3 \%$ of small enterprises operated in the sphere of real estate operations, rent and services. Currently, a small business in Russia acts primarily as an intermediary between producers and consumers, preferring sphere with a fast turnover. The existing structure does not allow a small business as a whole to be considered the carrier of innovation or innovation driver. The reduction of the role of small business to mediate limits the potential of the real sector of the economy (Ketko, Zarafutdinov, 2011). 
Fig. 2: The branch structure of small business in 2014

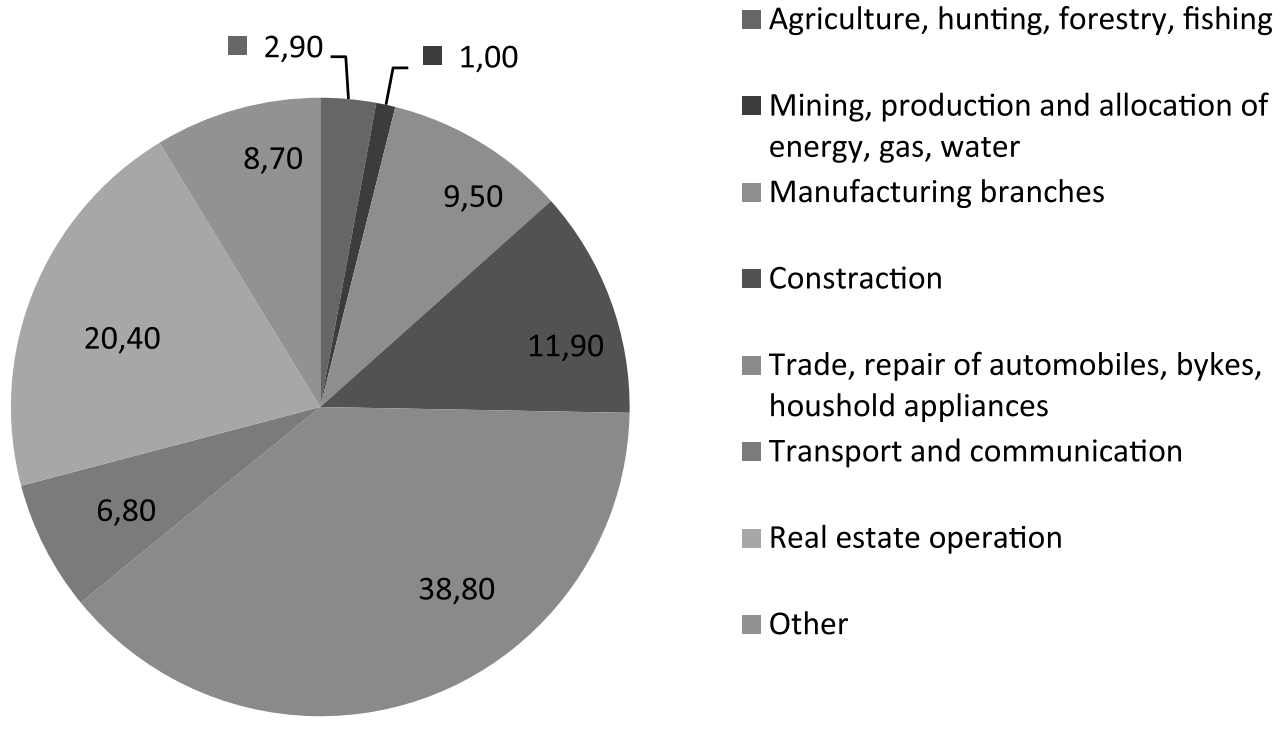

In 2014, the ratio of profitable and loss-making enterprises of micro and small businesses amounted to 80:20, i.e. every fifth company was unprofitable (tab. 4). A similar ratio was observed in previous years.

Table 4: Financial results of small businesses in 2010-2014

\begin{tabular}{|l|r|r|r|r|r|}
\hline \multirow{2}{*}{$\begin{array}{l}\text { Number of } \\
\text { enterprises }\end{array}$} & \multicolumn{5}{|c|}{ including } \\
\cline { 3 - 6 } & & $\begin{array}{c}\text { Profitable enterprises } \\
\text { number of } \\
\text { enterprises }\end{array}$ & $\begin{array}{c}\text { profit, mln } \\
\text { rub. }\end{array}$ & $\begin{array}{r}\text { Lumber of } \\
\text { enterprises }\end{array}$ & $\begin{array}{c}\text { loss, mln } \\
\text { rub. }\end{array}$ \\
\hline Micro-enterprises \\
\hline 2010 & 435119 & 347183 & 457694 & 87936 & 216676 \\
\hline 2011 & 406206 & 331200 & 369548 & 75006 & 170479 \\
\hline 2012 & 500314 & 412360 & 715371 & 87954 & 177090 \\
\hline 2013 & 1155668 & 931644 & 1297496 & 224024 & 447613 \\
\hline 2014 & 1328352 & 1061436 & 1648981 & 266916 & 749455 \\
\hline Small and micro-enterprises & & & & \\
\hline 2010 & 525399 & 416778 & 868401 & 108621 & 332407 \\
\hline 2011 & 495484 & 402641 & 776796 & 92843 & 302628 \\
\hline 2012 & 602698 & 496030 & 1256205 & 106668 & 305994 \\
\hline 2013 & 1344849 & 1082082 & 2093226 & 262767 & 656174 \\
\hline 2014 & 1530294 & 1219954 & 2548634 & 310340 & 1337684 \\
\hline
\end{tabular}


Dynamics of the ratio of small enterprises, including micro-, total net financial result to the total revenue is shown in Fig. 3. Over the past 5 years, this figure peaked in 2013 and amounted to $5.80 \%$. In 2014, the figure was $4.59 \%$. Thus, total profitability of the small business sector amounted to $4.81 \%$ in 2014 , which does not allow affirming the economic efficiency of small business as a whole.

Fig. 3: The dynamics of the ratio of net financial result to revenue of small businesses

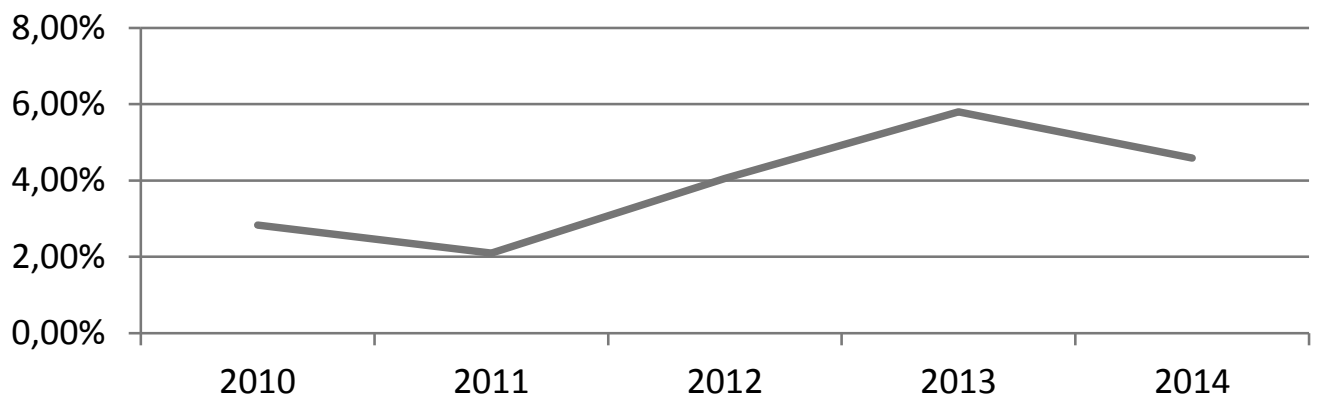

Also it should be noted that the average revenue of small enterprises in 2014 amounted to $17.25 \mathrm{mln}$ rub., which is much lower than the statutory limits. This fact reinforces the assertion that the scale of the economic activity of small enterprises varies widely. Legislatively established possibility of increasing revenue in the current situation is hardly an incentive for most small businesses.

Thus, the inclusion of 2014 data to the analysis helped confirm the earlier conclusion that most clearly manifested features of small business in Russia in modern conditions are self-employed and meet the demand in the local markets, which is particularly important in the framework of import substitution policies (Antokhina, Guzikova, Vidyakina, 2015).

In 2015, the auditing firm KPMG conducted a survey of small and mediumsized businesses in Russia to identify problems that hinder small business development. In the survey of more than ten thousand questionnaires and $578 \mathrm{com}$ ments, in which the businessmen described their difficulties informally, were collected in 82 regions of the country (Expensive loans, 2015).

The most urgent problem was the limited access to financial resources, noted by $50 \%$ of respondents. Also were noted the difficulty of obtaining credit for the long term, high interest rates and the inability to get a loan with deferred payments extinctive. In previous years, the most urgent problem of the small business owners was a bad business climate. Now the financing difficulties came in the first place as the crisis in the economy continues. It may be noted that the representatives of the government see the reason for this situation in the high level of inflation and associate prospects of its change with the control over inflation and its decline to $4-5 \%$. 
Bad business climate appeared the second topical issue in 2014 that $30 \%$ of respondents noted. The problem manifests itself in frequent changes in legislation, bureaucracy, frequent inspections and a lack of interest in the development of entrepreneurship from municipal authorities.

In 2015 federal law was issued according to which the state and municipal routine inspections of small businesses are prohibited for the period from 1 January 2016 on 31 December 2018. The law does not apply to fire, environmental, radiation surveillance, control in the field of state secret protection and use of nuclear energy. However, in recent period, regulations have been adopted aimed at increasing fiscal and non-fiscal burden on small business and the establishing new administrative barriers, which exacerbates the situation of small businesses on the background of economic crisis (Kalinin, 2015).

The low training of young cadre was named as the third of urgency. Among the topical issues were also attributed difficulties of access to markets, search for goods and services suppliers, access to production technologies, training and infrastructure. In the comments, entrepreneurs mentioned high taxes and an increase of tax burden, competition, illegal business, growth of retail chains, actively interacting with the "administrative resource", the high cost of connection to the power grid, the electricity tariffs.

According to the entrepreneurs' opinion, the state should support primarily intellectual production (computer science, science, art). Further the industry of the means of production and other producing sectors (construction, production of consumer goods, raw materials) were pointed. According to experts, not producing industries - service sector, trade and finance - need the support least of all (Golubev, 2003).

The survey of Alfa-Bank (Anikeva, 2015) identified that owners and managers of small businesses currently see their main objectives in searching and attracting more customers, increasing profitability, reducing costs, penetrating to new market segments, searching partners and suppliers. A significant part of small businesses have revised sales models, pays more attention to measures to increase customer loyalty, offers new products and services and working on their quality, invests in staff training. Thus, inflation and the growing complexity of the economy generate entrepreneurs striving to survive and strengthen their positions in the market. 


\section{CONCLUSION}

The current state of small business in Russia is determined by the general economic downturn.

The situation in small business is characterized by a gap between the aspiration of the majority of entrepreneurs to achieve tangible goals, motivating them to engage in business, and actually achieved results. Significant part of entrepreneurs is forced to participate in business, in particular, under the threat of unemployment. In general, neither motivation for enrichment nor forced involvement in business contributes to stabilization and development of the small business economy and its adoption of the innovative role.

In recent years, there has been an increase in the tax burden on the background of certain administrative relaxations that due to general decline in incomes and the prevailing motivation for enrichment can lead to the expansion of the informal, uncontrolled by state sector. Expansion of quantitative criteria of small business in terms of turnover meets the interests of a small number of businesses without affecting the interests of the majority.

There is enough well-formulated range of small business concerns, which should serve as a guide in the development of policies related to small business, in which the main emphasis should be placed on the regional level allowing to take into account the regional specificities and differences. An important condition that can ensure the survival of small businesses in the economic downturn is their understanding the need to change approaches to business model and working methods. 


\section{Literature}

- Anikeeva M. (2015): Small Business in Russia starts for Long Distance. URL:

- http://www.spb.kp.ru/daily/2647/3344853/ [In Russian]

- Antokhina, Y.A., Guzikova, L.A., Vidyakina, V.A. (2015): Economic Role of Small Business in Russia Today. Business. Education. Low. Bulletin of the Volgograd Institute of Business. 4(33), 2015 URL: http://vestnik.volbi.ru/upload/ numbers/433/article-433-1468.pdf [In Russian]

- Brunova, V.I. (2010): Basics of Entrepreneurship (2010): Ed. V.I.Brunova. Saint-Petersburg. 2010. 106 p. [In Russian]

- Edovina, T. (2014): Entrepreneurship grows forced pace. URL: http:// kommersant.ru/doc/2564149 [In Russian]

- Expensive loans, shortage of skilled workers, a poor business climate. (2015) URL: http://ibusiness.ru/blog/experience/40108 [In Russian]

- Golubev, A.V. (2003): Social Portrait of Now-days Entrepreneur URL: http:// www.maecenas.ru/doc/2003_9_3.html [In Russian]

- Guryanov, P.A. (2011): The social Image of the Entrepreneur in Russia. Modern Scientific Research and Innovation. 2011. № 4 URL: http://web.snauka.ru/issues/2011/08/1632 (access date: 07.04.2016). [In Russian]

- Kalinin A. (2015): Few and slowly. Russian Business Newspaper. №993 (14) URL: http://rg.ru/2015/04/14/dola.html [In Russian]

- Keeble, D. (1990): New firm and regional economic development: Experience and impacts in the 1980s. Cambridge Regional Review, 1, 19-38

- 10 Ketko, N.V., Zarafutdinov, R.R. (2011): Problems and prospects of development of small business in modern Russia. Russian Entrepreneurship. 2011. №9, iss. 1(191). - p. 23-28. URL:

- http://old.creativeconomy.ru/articles/13161/ [In Russian]

- Kruglov, A.V. (2004): Regulation of the external and internal environment of business organizations as a basis for sustainable development. News of SPSUEF. 2004. № 4. - p. 68 [In Russian]

- Motivational structure of Russian businessman (2006): Problems of the theory and practice of management. 2006. № 4 - p. 112. [In Russian]

- Rasskazova, N.V. (2008): Conceptual problems of the theory of entrepreneurship and change economic paradigm. News of Penza State Pedagogical University named by V.G.Belinsky. № 11. 2008. - p. 68-72 [In Russian]

- Rumyantsev, M.A. (2008): Orthodoxy and the social responsibility of business. Problems of Modern Economics. 2008 №3 - p. 510 [In Russian]

- Theoretical aspects of entrepreneurship and entrepreneurs. (2014) URL: http://www.psycademy.ru/pages/525/ [In Russian] 


\section{LiUdMILA Guzikova}

Sanktpeterburški politehnički univerzitet Petra Velikog, Sankt Peterburg, Rusija

\section{MALA PREDUZEĆA U RUSIJI KAO EKONOMSKI I SOCIOLOŠKI FENOMEN}

Danas su mala preduzeća nesumnjivo važan deo nacionalnih privreda širom sveta. Problematika razvoja malih preduzeća je jedna od najpopularnijih oblasti istraživanja za ruske istraživače devedesetih godina prošlog veka. Nakon što je počela reforma tržišta, veliki deo stanovništva verovao je da će mala preduzeća postati izvor bogatstva i blagostanja, kako za njih lično tako i za društvo u celini. Ovo mišljenje je ujedinilo akademske istraživače i preduzetnike, tako da su aktivnosti drugih obezbedivale empirijski materijal za prve. Glavne ekonomske funkcije koje se obično pripisuju malim preduzećima su: inovacije, borba protiv monopola i održavanje konkurentnog okruženja, borba protiv nezaposlenosti i otvaranje novih radnih mesta, povećanje prihoda u opštoj populaciji $i$, samim tim, uvećanje tražnje potrošača, povećanje profesionalne delatnosti, razvoj preduzetničkih veština, duha i tradicije. Društvena uloga malih preduzeća smatra se važnom institucijom civilnog društva i jezgro formiranja srednje klase kao osnove za društvenopolitičku stabilnost države. U ranijem istraživanju autora zaključeno je da u današnjoj Rusiji mala preduzeća ne obavljaju pravilno funkcije koje su im pripisane u ekonomskoj teoriji. Njihov doprinos inovacijama je skroman. Njihova antimonopolska uloga ne uklapa se u teorijski stav. Uloga u otvaranju novih radnih mesta je primetna, ali nije praćena stvaranjem prihoda i odgovarajućim pokazateljima poslovne produktivnosti. Cilj ovog istraživanja je da odredi i objasni specifičnosti malih preduzeća u Rusiji u kontekstu ekonomske teorije i društvenih procesa na osnovu statističkih podataka i činjenica.

Ključne reči: mala preduzeća, preduzetništvo, inovacije, konkurentno okruženje, prihod u malim preduzećima 